\title{
AN ANIMAL-STANDPOINT READING OF FAREWELL GUL'SARY BY CHINGIZ AITMATOV ${ }^{1}$
}

\author{
Cengiz Aytmatov'un Elveda Gülsarı Romanının Hayvan Odaklı Eleştiri Açısından İncelenmesi
}

\author{
Gülsüm Tuğçe ÇETíN²
}

\begin{abstract}
As a sub-genre of ecocriticism, animal-standpoint criticism particularly traces the moral status of the animals and therefore if they have any rights or not in the literary texts. Such a criticism also examines the works of literature taking into consideration the ways animals are treated and what their roles or standpoints are. Animal-standpoint criticism, which has equal consideration for the animals at the core, rejects speciesism. In this respect, as a reflection of speciesism in literature, figurative use of the animals and the narration that excludes the animals' condition and makes them not visible are criticized by such a criticism. In this context, Chingiz Aitmatov's internalised writings, long before the theory had been constructed, dealing with nature and animals are accepted as pioneer narrations. This study aims to examine the novel Farewell Gul'sary by Chingiz Aitmatov, considering the novel as a beyond time example in the respect of animal-standpoint criticism.
\end{abstract}

Keywords: Animal-Standpoint Criticism, Chingiz Aitmatov, Farewell Gul'sary.

$\ddot{\mathbf{O z}}$

Ekoeleştirinin alt dalı olan hayvan odaklı eleştiri edebi eserler üzerinden hayvanların ahlaki durumunun ve hayvan haklarına sahip olup olmadıklarının izini sürer. $\mathrm{Bu}$ anlayışla, edebi metinlerde hayvanlara nasıl muamele edildiğini ve hayvanların yazındaki rollerini inceler. Söz konusu hayvanlar olunca eşdeğer düşünce ilkesini temel alan hayvan odaklı eleştiri yöntemi türcülüğ̈̈ reddeder. Bu bakımdan, türcülüğün edebiyattaki yansıması olarak hayvanların sembolik kullanımı, fiziksel olarak varlıklarının yok sayılması ve görünmez kılınmaları eleştirilir. Bu bağlamda, hayvan odaklı eleştiri kuramı oluşturulmadan önce, Cengiz Aytmatov'un doğa ve hayvan odaklı içselleştirilmiş yazıları öncü anlatılardan kabul edilmektedir. Bu çalışma, Aytmatov'un Elveda Gülsarı romanını hayvan odaklı bakış açısıyla zamanının ötesinde bir roman olarak incelemeyi ve hayvan insan ilişkisini irdelemeyi amaç edinir.

Anahtar kelimeler: Hayvan Odaklı Eleştiri, Cengiz Aytmatov, Elveda Gülsarı.

\section{Introduction}

Animal-centric or animal-standpoint criticism, as a sub-genre of ecocriticism, particularly traces the moral status of the animals and examines if they have any rights or not in the literary works. As ecocriticism "is a form of philosophical liberation from logocentric and anthropocentric thought" (Oppermann, 2011: 459), animal-standpoint criticism, which is based on ecocriticism, is a viable theoretical background of accepting the animals as moral entities, who have sensibility, the capacity to feel pain, and experience pleasure that unite humans with animals (Donovan, 1990: 353-356). Within the scope of moral status, such a criticism also examines the works of literature taking into account the way animals are treated and what their roles or standpoints are. In animal-standpoint criticism, which has an ethical background, the major criticism is towards anthropocentrism and

\footnotetext{
${ }^{1}$ This article is a revised and expanded version of the paper with the same title, presented at $7^{\text {th }}$ International Comparative Literature Congress hosted by Cumhuriyet University in October-2018 and has not been published anywhere before.

${ }^{2}$ Arş. Gör., Frrat Üniversitesi İnsani ve Sosyal Bilimler Fakültesi. ELAZIĞ

e-posta: gtcetin@firat.edu.tr, ORCID: https://orcid.org/0000-0002-6376-6113
} 


\section{F.Ü. Sosyal Bilimler Dergisi 2020-30/1}

speciesism. Peter Singer's Animal Liberation is a path-breaking work in this field. Equality for animals is the principal point that underlies the argument; however, "the basic principle of equality does not require equal or identical treatment; it requires equal consideration" (Singer, 2002: 2). In this respect, animal-standpoint criticism definitely rejects speciesism, which prefers human being to other creatures and defends that they have the rights that the others do not (Singer, 2002: 160).

The animal-standpoint eye gives illuminating ideas to understand nature in many aspects. Therefore, the figurative use of animals and speciesist identifications and representations of the animals in the literary works are criticized by that critical theory. It also critiques the narration that eludes the animal and makes the animal being almost invisible. In such narrations the independent animal being is seen only as an object; and as the author is silent for these "objects", the reader cannot hear them. In this respect, animal-standpoint approach requires the animals to speak for themselves, and in this study, it is intended to track the speaking animals and make them visible. Indeed, the narrations that objectify the animals are the reflections of real-life and the foregone conclusion of the hereditary anthropocentricism, which promotes humanity as the centre of the universe. This social transposition, which values human-animals above non-human animals, has been an incremental misbehaviour for many years. In order to understand this transgenic state of the superiority of human being, it will be useful to look at the origins of classical anthropocentricism and how animalstandpoint criticism develops as a reaction to it.

\section{From Classical Anthropocentricism to Animal-Standpoint Criticism}

How was the man's dominion inherited to us, to the human being, as the dominant animal in nature? The religious narrations about the creation and the place of human being in the universe can be regarded as the primary factors of the genealogical anthropocentricism. It should be noted that there is no intention to imply any mentioned or not mentioned religions or religious books as inferior, and the quoted passages are not chosen by any malicious intentions. The Holy Bible echoes,

And God said, Let the earth bring forth the living creature after his kind, cattle, and creeping thing, and beast of the earth after his kind: and it was so.

And God made the beast of the earth after his kind, and cattle after their kind, and every thing that creepeth upon the earth after his kind: and God saw that it was good.

And God said, Let us make man in our image, after our likeness: and let them have dominion over the fish of the sea, and over the fowl of the air, and over the cattle, and over all the earth, and over every creeping thing that creepeth upon the earth.

So God created man in his own image, in the image of God created he him; male and female created he them.

And God blessed them, and God said unto them, Be fruitful, and multiply, and replenish the earth, and subdue it: and have dominion over the fish of the sea, and over the fowl of the air, and over every living thing that moveth upon the earth (Genesis I: 24-28).

The Bible narrates that the man is created from God's own image and God gives the priority to man to dominate other creatures in the world. The land and the sea, ground and high, everywhere is under the command of human being. As God is the creator and the ruler of the universe, the man, as the image of God, is the dominator of the earth. In this context, Christianity, in its western perception, is asserted as "the most anthropocentric religion the world has seen" (White, Jr., 1996: 9). The religious narrations, which are the roots of constructing an interpretation of life and influence every aspect of human being's life, occupy an important position for humanity in regarding itself as the centre of existence. We can find similar narrations in the Quran as well. The Holy Quran tells us that God, 
Who perfected everything which He created and began the creation of man from clay.

Then He made his posterity out of the extract of a liquid disdained.

Then He proportioned him and breathed into him from His [created] soul and made for you hearing and vision and hearts; little are you grateful (Quran, Al-Sajdah, 7-9).

The man is brought to life with the breath of God and human being is created from His own image. As the reflection of God, human being automatically comes to a position of the mere ruler of the created world; no one but the man, who has the breath of God in his soul, becomes the dominator of all living and non-living creatures. The rest of the creatures are created to serve the human being.

Do they not see that We have created for them from what Our hands have made, grazing livestock, and [then] they are their owners?

And We have tamed them for them, so some of them they ride, and some of them they eat.

And for them therein are [other] benefits and drinks, so will they not be grateful? (Quran, Ya-Sin, 71-73)

The Holy Quran clearly declares that the living and non-living creatures are created to serve human being. The animals are domesticated for human being in order to provide a comfortable life. Therefore, human being has the right to dominate and use them for his own benefit. Actually, wanton cruelty towards animals is forbidden by the Quran and the dominion of the man requires a responsibility to God. However, as result of the misinterpretation of some discourses, human sovereignty is excused based on them. Thus, in terms of the care for the animals being ruled, the superiority of humans is repeated and underlined.

Beyond these religious narrations, which explicitly celebrate the dominance of human being, the ancient philosophical tradition states that animal beings cannot have any moral value while asserting that the human race is superior. In other words, this tradition, putting human being at the centre, asserts that human being is prior to animal beings that lack spirit, logic, consciousness, and individualism (McMahan, 2003: 525-526). According to Aristotle, whose support for slavery is quite clear, male and free humans are at the centre of the universe, and thus, he is the absolute creation. Believing that some people are slaves by nature and some are masters, and slavery is a right for the masters, Aristotle naturally believes in slave-master relationship. His interpretation of the hierarchy among human beings can be widened to the relationship between human and non-human beings. In this context, as the human being is considered to be created as the absolute being in the universe, as the master; the rest of the world has to serve them, as slaves, and this is a right by nature. Aristotle's words in Politics supports the hierarchy in nature:

Plants exist for the sake of animals, and brute beasts for the sake of man - domestic animals for his use and food, wild ones (or at any rate most of them) for food and other accessories of life, such as clothing and various tools.

Since nature makes nothing purposeless or in vain, it is undeniably true that she has made all animals for the sake of man (2013: 16).

The human being, who is at the top of the pyramid, has an explicit supremacy over the rest of the living creatures. In this order, in which everything is bound to one another, every organism directly or indirectly exists for man. Man is the sole motive of the existence for the other creations.

In the first half of the seventeenth century, René Descartes brought a new and mechanical explanation by giving up classical theological attitudes. His famous cogito, "I think, therefore I am." celebrates that thought and reason are sine qua non for existence. Descartes was not only a modern 


\section{F.Ü. Sosyal Bilimler Dergisi 2020-30/1}

thinker and the father of modern philosophy but also a Christian, which makes it possible for him to combine religious and scientific thoughts. Therefore, the outcome of Descartes's philosophy is "animals do not have immortal souls [...] they do not have consciousness either. They are [...] mere machines, automata" (Singer, 2002: 200). Descartes believes that the animals are nothing but automats; therefore, their behaviour can be explained just by mechanical reasoning, and they cannot be the subject of any moral interest. In this sense, as the animals just belong to this world, human being does not have any responsibility for these automated and mortal creatures.

Another important name of Enlightenment, Immanuel Kant, believes that human beings and animals both have instincts; however, the human being has also consciousness. To Kant, as the animals do not have any rationality to decide what to do, they have value just as tool:

But since all animals exist only as means, and not for their own sakes, in that they have no self-consciousness, whereas man is the end, such that I can no longer ask: Why does he exist?, as can be done with animals, it follows that we have no immediate duties to animals (1997: 212).

From the perspective of Kant, as far as animals are concerned we have no care duties. The reason for animals' existence is to be a tool for the subject, for human being. If a man treats animals kindly, the source of this virtual behaviour is the responsibility of mankind, but nothing related to the animal's sole presence because "animals are regarded as man's instruments" (Kant, 1997: 213). The traditional humanist understanding, in the environmental consideration, goes on to maintain the superior position of human being. To Bookchin, human species is the member of "first nature", which refers to the nonhuman world including other animals in nature; however, humans create a "second nature" referring to culture, which gives the right to change and control the nonhuman nature (1987: 20). In such an atmosphere, in which conventional human dominance passes down, animal studies provide a fresh breath for the relations of both human and non-human beings. In the literary world, the agent of that protest is animal-standpoint criticism.

Within literary studies, animal-standpoint criticism discusses the dimensions of thought and action involved in specific poetic choices of the literary works dealing with animals. John Simons, one of the leading critics in that field, notes that "the changes in attitudes towards animals [...] are now such an important part of popular consciousness and public debate" (2002: 5), with an opposed perspective against the aesthetic exploitation of animals. Therefore, "the cultural text and, specifically, a piece of literature" carries importance in seeking "for the tracks of animals" (Simons, 2002: 6) within the context of such a critical understanding. In a tradition that "continues to draw heavily on symbolic ideas involving animals and that the immediate subject of those ideas is frequently not the animal itself, but rather a human subject drawing on animal imagery to make a statement about human identity" (Baker, 1993: ix), the figurative exploitation of animals is considerably regarded as normal. On the other hand, Simons interposes "animals are not symbols", and he also protests the consuming of the representations of the non-human by the human because the animals are as real as humans (2002: 6-7). That standpoint dramatically rejects the normalised disregarding of the animals by the humans. To Campbell, biocentrism is the primary objection to this classical hierarchy in nature, which refers to "the conviction that humans are neither better nor worse than other creatures (animals, plants, bacteria, rocks, rivers) but simply equal to everything else in the natural world" (1996: 128). This approach, which accepts every creature in the world as equal, is extended to the literary tradition with this critical understanding. To put it simply, animal-standpoint criticism aims to reconstruct the conventional beliefs of writing with regards to animal rights.

In the existing literary tradition, it is possible to explore the samples of the narrations in which animals are utilised just to fill the blanks through the usage of figurative language with the aim of signifying human being. Arguing that using animals as symbols or metaphors through the medium of language is quite common, Carol J. Adams notes that "animals are made absent through language" and she adds that using animal literally is to elude them by the signifier, by the subject; therefore, 
animals become "absent referents" and "the absent referent permits us to forget about the animal as an independent entity" (2010: 66). In the perspective of animal-standpoint criticism, Adams declares that animals, in the literary studies, "have become absent referents, whose fate is transmuted into a metaphor for someone else's existence or fate [...] in this case the original meaning of the animal's fates is absorbed into a human-centered hierarchy" (2010: 67). The actual position of the absent referent is in between; perceptibly it is there but it is dismantled by the subject. Hence, in a literary understanding that is built with a perception of accepting nature as dumb, animal-standpoint criticism opposes to the silence of the animals, which are transformed into only symbolic presences with the anthropocentric discourse.

Animal-standpoint criticism aims to bring the animals to life with their uniqueness as the subjects. The objectified animal is no longer a being; thus, such a criticism requires equal consideration in the literary texts. Therefore, aestheticized animals should be seen with a sympathetic eye by the reader, and this is only possible with a writing of consideration. In this respect, how human domination over non-human operates in Gul'sary and how a not-objectified animal is reflected in the novel will be discussed.

\section{Aitmatov and Gul'sary}

The point that makes Aitmatov so important in the medium of empathetic treatment towards animals and nature is his foresighted literary ability in his Farewell Gul'sary (1963), which was written long before the literary movements about nature and animals through the world appeared. In this respect, Aitmatov is a writer who thinks beyond the time and narrates that human fate is intertwined with the other creatures in the universe (Korkmaz, 2009: 17). Bilge Ercilasun, who is the first writer that mentions Aitmatov's writing in terms of nature, states that he uses the natural elements with both symbolic and aesthetic aims (2013: 421). Aitmatov's ecocritical perspective is deep and his view of nature is not similar to that of a Romantic writer, but that of a conscious environmentalist (Gökalp Alpaslan, 2014: 13). His tendency to write about animals, and narrate them not as the background objects is a crucial point that adds a universal value to his works.

In Chingiz Aitmatov's Farewell Gul'sary, we find the writer's empathetic and sensitive approach to a horse. The novel, which is constructed with the memoirs of Gul'sary and his elderly owner Tanabai, is narrated through the omniscient third person point of view. The writer's narration is equidistant both to the animal and to the human being. Therefore, the writer does not belaud any kind of species, rather he reflects his anti-anthropocentric stance from the beginning of the narration. The life stories of Gul'sary and Tanabai are narrated so empathetically that the reader can extend her/his perspective to the animal's and adopt a wider and different attitude towards the world. In this process, Aitmatov does not aim to personify the animal but he aims to make the human being view the world and life as a non-human being. The story centres upon the horse - from his young and famous times to his old age and death - and the horse is not silenced by the writer, but allowed to speak out. Even though we live in a culture that accepts nature as dumb, Aitmatov interprets the world as a whole and capable of communication. The writer's equidistant stance towards both the animal and the human being echoes in the empathetic expression in the novel, which says the same destiny would be shared by the two species: "Do you think that either of us look any better? Everyone grows older" (Aitmatov, 1970: 24) ${ }^{3}$. As it can be inferred, time does not favour any creature, all beings are equal before nature and time.

The horse's own feelings are described by the writer in detail. The detailed descriptions enable the reader to share the excitement of the horse and to perceive Gul'sary as a subject. Gul'sary's happiness becomes the reader's happiness and Gul'sary's sadness becomes the reader's sadness.

\footnotetext{
${ }^{3}$ The references to Farewell Gul'sary will be given with page numbers only henceforth.
} 


\section{F.ய̈. Sosyal Bilimler Dergisi 2020-30/1}

"Chu, Gul'sary, chu," he heard his master's voice. The sun came more quickly towards him. One by one the faces of the ricers, distorted with anger, were passed and left behind, as were the slashing whips and the grunting mouths of the horses. Suddenly the drag of bit and rein vanished. It seemed to Gul'sary that there was neither saddle nor rider on his back only deep inside him the burning passion of the race.

[...]

Suddenly, distinctly, he heard "Gul'sary! Gul'sary! Gul'sary!" and these shouts he gathered in, these cries and yells, they filled him as if with fresh air and he raced down with new strength (56-57).

Gul'sary as a subject is demonstrated with the narration from the horse's direct point of view, without personification, and his true existence is underlined with an equal stance. He is not fictionalised as a background object, but his feelings and experiences are described as a subject. The detailed narration of the animal acknowledges that he is a living and feeling creature. Moreover, Aitmatov lengthily gives place to the memory of Gul'sary and integrates the story with the horse's mind:

The feeling that the ground beneath his hooves was insecure brought back to the horse's fading memory [...]. He loved that moment when his mother suddenly turned into a gentle, quietly snorting cloud. Her teats became firm and sweet, the milk foamed on his lips and he choked with its abundance ad sweetness. He loved to stand there nuzzling at her. What ravishing, heady milk it was! His whole world - the sun, earth and his mother - was contained in a gulp of that milk. And even when he was sated, he could still enjoy one more gulp, and another, and another (19).

The memories of the horse are the tools to make connection between the past and the present. Gul'sary lives a life that he can evaluate his past and is aware of his present condition. In this context, Aitmatov narrates the horse as a being, who tries to realise the changes both in himself and around his environment and he is a being, who has a sense of self. As it can be clearly inferred, the writer's narration of the emotions, consciousness, and reactions of Gul'sary does not have anything common with anthropocentric stance. Aitmatov shows that more sympathy for the other creatures makes it easier to think of them as a creature beyond a thing.

The utilitarian position in animal rights is the outcome of the philosophy by Peter Singer. His philosophy supports the idea that sensibility, the capacity to feel pain, and experience pleasure are the common matters that gather human and animal beings. In this sense, Jeremy Bentham's words can be regarded as an echo of his consideration,

The day may come when the rest of the animal creation may acquire those rights which never could have been withholden from them but by the hand of tyranny ... It may one day come to be recognized that the number of the legs, the villosity of the skin, or the termination of the os sacrum are reasons equally insufficient for abandoning a sensitive being to the same fate ... The question is not, Can they reason? nor Can they talk? but, Can they suffer? (qtd. in Singer, 2002: 7)

From this point of view, Singer defends that if the animal has the capacity to have feelings, then has the right to have equal consideration and treatment by stating " $[t]$ he capacity for suffering and enjoyment is a prerequisite for having interests at all" (2002: 7). In the novel, Gul'sary has many moments that he derives pleasure. For example, he enjoys the smell when the familiar woman, Byubyuzhan, opens the door when he and his master go into her house; "there was the warm smell of her flesh and the strange smell of that herb, unknown to Gul'sary" (64). The horse is also pleased when he is being fondled by the woman as described in the novel as follows: "Byubyu, come here,' called Tanabai. 'Do come back and stroke him, caress him.' [...] 'Don't insult us'” (65); and the 
horse enjoys "her wonderful hands, soft and gentle like the lips of that bay filly with the star on her forehead" (66). As a growing up stallion, the horse's changing instincts take place in the novel, as well, "Gul'sary would have liked something different. [...] The power of a stallion was growing in him. [...] He neighed, was excited and nipped the fillies' legs. They obviously appreciated this and followed him, rousing the envy of the stallion. [...] How he missed the fillies" (66). In the novel, the reflected pleasure of the animal is supportive of the theory of the unity between human and nonhuman animals. The scenes that the horse is pleased are the very same to the human being's. Therefore, according to animal-standpoint criticism, if the senses are similar for the similar experiences, then it would be meaningful to say that equal consideration cannot be denied.

While Chingiz Aitmatov is narrating the story of Gul'sary from the animal's direct point of view, he makes more visible and sensible the sufferings of the horse. He mentions the experiences not by personifying the horse, but strictly emphasizing his true being. This narration style makes it possible for the reader to clearly see the oppressive and destructive tendency of the human being towards the animal. After reading the impressive passage that narrates the moment when Gul'sary is saddled by his owner, the reader comes to a point to question the relationship between human and non-human animals. In the novel, on the day Gul'sary and the other horses are gathered up by their owners to lick the salt, Gul'sary recognises the noose but is not afraid of being caught up because he knows that these nooses are for the milking mares and riding horses. However, this time the noose is for Gul'sary. Until he wants to go to the river to drink, he does not recognise the rope, which is the new tool to control his independence. As he recognises the noose on his neck,

[t]error seized the pacer. He pranced again, again and again. The sunlight was flashing in his eyes and scattering in bright circles; the earth, the mountains, the people around were falling, and toppling over backwards. For a moment a frightening empty blackness covered his eyes and he struck out at it with his forelegs (37).

This impressive part in which Gul'sary is subdued by his master ends with human being's victory and animal's resignation. In the end, the order is organised in the way that human being desired. From the master's point of view, what should have done is done, but from the stance of the horse his independence is exterminated with a meaningless and painful act. As Griffin notes, "whatever thoughts and feelings nonhuman animals experience may be quite different from ours, and presumably much simpler; but this does not mean that they are insignificant" (1992: 4). To animal-standpoint criticism, non-human animals do not have a developed thinking web, which is clinched through language; however, it does not mean to have superiority over the less developed species. Animal suffering should be taken into consideration. In the novel, the horse's suffering is reflected vividly: "His head was still swimming, the earth and the yurtas were revolving around him, swirling with the horses in the distance and the mountains and the clouds in the sky" (38). The horror of Gul'sary, who is very fond of freedom, when he experiences the feeling of the noose is undefinable for him because he is free by nature and he cannot give any meaning to this external oppression. The horse suffers both physically and emotionally. "If a being suffers there can be no moral justification for refusing to take that suffering into consideration. No matter what the nature of the being, the principle of equality requires that its suffering be counted equally with the like suffering [...] of any other being" (Singer, 2002: 8). It should be thought that if we could feel the suffering of the animal or understand the emotions of the animal, could it possible to repeat what we do to them? As Regan notes, "an animal's right to live free from suffering should be just as important as a person's" (2003: 121). To put it simply, human oppression towards animals is neither natural nor a right.

Perkins states that in many novels, memoirs, and travel books, which "include the scenes of travel by coach", "the horses are sometimes mentioned but their sufferings almost never. They were invisible to most passengers or, perhaps the novelist considered them irrelevant to the theme of the novel" (2003: 105). While general inclination is that animals are only servants to the humans, in the 


\section{F.Ü. Sosyal Bilimler Dergisi 2020-30/1}

novel the horse is a friend and analogue to the life of his master, Tanabai. Therefore, adopting an anti-speciesist attitude towards the animal characters in the fictions, Aitmatov is the speaker of the sufferings of the animals. He fills the absences that are created by the anthropocentric tradition focusing on the true essence of Gul'sary. As Fudge notes "the truly meaningful animal is often a very individualized being" (2000: 110). As an individualised being, Gul'sary is given serious moral attention by his detailed descriptions, which are the indicators that the horse is a separate creature, worthy of attention in his own right.

"You see few of them. In the old days he would have been priceless. People would have fought to the death for one like that."

$[\ldots]$

"He's a good one, touch wood," agreed the old man, "but take care." He became serious and scratched the back of his neck. "Ride him yourself in the spring and above all, don't gossip about him. There are as many hunters after a pacer as there are after a pretty young girl. If a girl falls into good hands, she'll flourish and delight the eyes. But if she get's a wrong'un, you can only suffer when you see her. And you cannot do a thing to help. It's the same with a good horse. It is easy to ruin him and he will fall in full gallop" (30-31).

Aitmatov fictionalises the animal as an autonomous being that is aware of the changes trying to understand what is happening. From an animal-standpoint perspective, if the animals have the capability to comprehend anything, they also have the consciousness of their own activities and their selves (Griffin, 1992: 248-249). Therefore, it is important for non-human animals, who have selfawareness, to be treated equally and not to be exposed to pain, which is morally wrong.

The descriptions of the pains from Gul'sary's point of view make it possible to see how an animal becomes the captive of a human being while it is actually a part of nature. The vivid descriptions of his anger, pain, and his resignation aftermath are the indicators of the oppression of one species to the other. When the owner of Gul'sary changes, he actually becomes the victim of the human relationships; he is physically imprisoned and "[i]t was the first time he had been in such a stable, a prison for horses" (82). When he is demanded by the president of the kolkhoz to the stables, Tanabai does not want to give up Gul'sary. Even though Tanabai's all efforts not to give the horse away, he knows that he is raising the horses for riding purposes for the others. At the end, he is forced to surrender and the horse is taken away. Although the horse is captured by force and fettered, he is emotionally united to his first master, Tanabai, and repeatedly escapes from the stable in order to go to him. At last, Tanabai sees Gul'sary with the fetters on his legs and the man goes mad and spills out hatred against the president: "[T]ell him from me that if he once again puts them on the pacer, I'll brain him with them" (89). However, his anger is take out on the horse. The quarrel between two people is culminated in Gul'sary's castration. This section is one of the most striking reflections of human persecution. The horse is unaware of what is happening.

Some hand were at work between his hind legs.

[...]

Gul'sary stiffened from the blows and pressure and the touch of something cold.

His new master squatted there in front of him, watching, waiting for something.

Suddenly there was a dreadful pain which exploded like a flash in his eyes. Oh!

There seemed to be a bright red flash and then everything went black, quite black...

When all was over Gul'sary lay there a long time, still tethered. The blood had to clot (93-94).

Gul'sary is punished by his master as he does not surrender. He pays for attempting to be a free horse. The human being's cruelty and the animal being's helplessness are obvious; however, 
Aitmatov does not leave Gul'sary alone and makes the reader the witness of the pain. Pain is pain, so the species of the subject of the pain does not matter. As Singer cogently devotes:

The application of the principle of equality to the infliction of suffering is, in theory at least, fairly straightforward. Pain and suffering are in themselves bad and should be prevented or minimized, irrespective of the race, sex, or species of the being that suffers. How bad a pain is depends on how intense it is and how long it lasts, but pains of the same intensity and duration are equally bad, whether felt by humans or animals (2002: 17).

Belonging to other species does not diminish the necessity of preventing unnecessary and arbitrary suffering. To Gerard, "[t]he boundary between human and animal is arbitrary and, moreover, irrelevant, since we share with animals a capacity for suffering that only the hand of tyranny could ignore" (2003: 137). As it is reflected in the novel, human tyranny shows itself in the embodiment of the new president of the kolhoz, as Gul'sary is seen only as an object to be captured and to be used as a tool to show their power. On the other hand, the unification between Tanabai and Gul'sary is the illustration of the emotional tie between the two species. From an ethical perspective, we must "escape all responsibility for activities that directly or indirectly cause the injury, death, and suffering of other animals" (Griffin, 1992: 246). In a world that human tyranny is obvious in a literary and real sense, Aitmatov makes the pains of Gul'sary visible and perceivable through literature. By narrating Gul'sary's inner feelings, thoughts and even pains, Aitmatov effectively creates animalstand point approach. Especially, within the scene of Gul'sary's castration, Aitmatov evokes feelings of sadness, empathy, and sympathy on the reader. On the other hand, the reader cannot help being furies with their own species for being the cause of the pain of this admirable animal.

\section{Conclusion}

Chingiz Aitmatov, whose ties with nature are quite tight, indicates the harmony between nature and its residents, not only in Farewell Gul'sary but also in his other novels. In the novel, the sentiments, pains, and pleasures are effectively portrayed. As the writer narrates the horse being loyal to his true essence, we can infer that Aitmatov carries the responsibilities of animal-standpoint approach. This stance provides an irresistible sympathy for the animal; thus, the reader is on the side of the non-human animal from the beginning. In this novel, Aitmatov is so delicate that he does not verbalise the thoughts and senses of the horse, but creates an eye, which looks into the internal and external world of the animal. In Aitmatov's world, human being is only one of the members of this universe, not superior, but an equal being. In this sense, to interiorise the differences and to accept the identical features between the species serve for a better empathic understanding in the shared world.

In terms of human's relationship with non-humans, the novel can be considered vital. Nature holding every single living thing inside can only be protected with a shared awareness and thinking beyond 'I'. In this sense, animal-standpoint criticism promotes literature, in which animals are paid attention to and not silenced by the speciesist ideology. As Tolstoy states "Art, should cause violence to be set aside $[\ldots]$ art can also evoke reverence for the dignity of every man and for the life of every animal" (Tolstoy, 1960: 190). In this respect, Aitmatov follows this notion as a writer, who internalises the true existence of animal beings. He puts an understanding of nature that is based on equality between the species, responsibility for the non-humans, and interdependency for a shared world. In this regard, Aitmatov has the common consciousness with animal ethics, which points out, "all animals are equal" (Singer, 2002: 1). He has forward-looking expectations in the way we treat and understand non-human animals.

Consequently, it could be argued that reconsideration of the relationship between human and non-human animals shall reconstruct the deconstructed system of nature. This can be achieved with an animal-standpoint perspective on the literary works. Aitmatov's writing, which concludes in 


\section{F.Ü. Sosyal Bilimler Dergisi 2020-30/1}

developing empathy and sympathy towards non-human animals, serves for revealing the horse's capability for living with joy and pain. Suffering is the kernel point that should be taken into account when all animals are discussed. If we would mention the right to equal consideration, in moral terms, then the capability of suffering should be taken into account. Therefore, as we all bleed, we all should have the right to equal consideration within the moral justifications. In the last chapter of the novel describing the death of the horse Gul'sary, while Tanabai says, "Farewell, Gul'sary" (191), Aitmatov welcomes an embracing approach to his human and non-human characters. He paves the way to question the boundaries and relations between humans and non-humans. As a consequence, it would be also true to say that Aitmatov is conscious of his responsibilities towards nature with his empathetic attitude to the horse. His narrative choice serves as a step to break the traditional anthropocentric hegemony, which dominates the twenty first century, and brings the reader to a closer position to the animal's inexpressible sensorial world.

\section{REFERENCES}

Adams, Carol J. (2010). The Sexual Politics of the Meat: A Feminist Vegetarian Critical Theory. NY: Continuum.

Aitmatov, Chingiz (1970). Farewell Gul'sary. (Translated by John Frence). GB: Hodder and Stoughon.

Aristotle (2013). Politics. United States: The University of Chicago Press.

Baker, Steve (1993). Picturing the Beast: Animals, Identity, and Representation. NY: Manchester University Press.

Bookchin, Murray (1987). "Social Ecology versus 'Deep Ecology': A Challenge for the Ecology Movement”. Green Perspectives, Newsletter of the Green Program Project 4-5 (Summer 1987). pp. 15-31.

Campbell, Sueellen (1996). "The Land and Language of Desire". The Ecocriticism Reader: Landmarks in Literary Ecology. Eds. Cheryll Glotfelty and Harold Fromm. Athens\&London: University of Georgia Press. pp. 124-136.

Donovan, Josephine (1990). “Animal Rights and Feminist Theory”. Signs, 15 (2). pp. 350-375.

Ercilasun, Bilge (2013). "Cengiz Aytmatov'un Romanlarında Tabiat". Türk Roman ve Hikayesi Üzerine. Ankara: Akçağ. pp. 415-422.

Fudge, Erica (2000). "Introduction to Special Issues: Reading Animals”. Worldviews, 4. pp. 101-113.

Gerard, Greg (2004). Ecocriticism. London and New York: Routledge.

Griffin, Donald R. (1992). Animal Minds. Chicago: The University of Chicago Press.

Gökalp Alparslan, Gonca (2014). “Cengiz Aytmatov’un Elveda Gülsarı, Dişi Kurdun Rüyaları, Ebedi Gelin: Dağlar Yıkıldığı Zaman Romanlarında Hayvan Zihni”. TÜBAR-XXXVI (Fall). pp. 11-26.

Kant, Immanuel (1997). Lectures on Ethics. USA: Cambridge University Press.

Korkmaz, Ramazan (2009). "Suların Sırrını Ödünçleyen İnsan: Aytmatov". Cengiz Aytmatov. Ed. Ramazan Korkmaz. Ankara: Kültür Bakanlığı Yayınları. pp. 13-19.

McMahan, Jeff (2003). "Animals". A Companion to Applied Ethics. Eds. R. G. Frey and Christopher Heath Wellman. Oxford: Blackwell Publishing. pp. 525-536.

Nasr, Seyyed Hossein (2015). The Study Quran, NY: Harper Collins Publishers.

Oppermann, S. (2011). "A Roundable Discussion on Ecocriticism". The Future of Ecocriticism. Eds. S. Oppermann, U. Özdağ, N. Özkan, and S. Slovic . Newcastle: Cambridge Scholars Publishing, pp. 459479.

Perkins, David (2003). Romanticism and Animal Rights: 1790-1830. NY: Cambridge University Press.

Regan, Tom (2003). Animal Rights, Human Wrongs: An Introduction to Moral Philosophy. USA: Rowman\&Littlefield Publishing Group. 
Simons, John (2002). Animal Rights and the Politics of Literary Representation. NY: Palgrave.

Singer, Peter (1993). Practical Ethics. USA: Cambridge University Press.

Singer, Peter (2002). Animal Liberation. NY: Harper Collins Publishers.

The Holy Bible, KJV, Collins Bible.

Tolstoy, Lev (1960). What is Art?, (Translated by A. Maude). Indianapolis: Bobbs-Merrill.

White, Jr., Lynn (1996). “The Historical Roots of Our Ecologic Crisis”. The Ecocriticism Reader: Landmarks in Literary Ecology. Eds. Cheryll Glotfelty and Harold Fromm. Athens\&London: University of Georgia Press. pp. 3-15. 
F.Ü. Sosyal Bilimler Dergisi 2020-30/1 